International Journal of Health Sciences
Available online at www.sciencescholar.us
Vol. 6 No. 1, April 2022, pages: $312-321$
e-ISSN: 2550-696X, p-ISSN: 2550-6978
https://doi.org/10.53730/ihs.v6n1.4214

\title{
Features of Choreography Teacher Activities in COVID-19 Pandemic Conditions and Distance Learning
}

\author{
Olga Bigus a , Dmytro Bazela ${ }^{b}$, Miroslav Keba $^{c}$, Tetiana Vynokurova ${ }^{d}$, Vira Poklad e Andriy Krys ${ }^{\mathrm{f}}$ \\ Manuscript submitted: 23 September 2021, Manuscript revised: 7 December 2021, Accepted for publication: 18 January 2022
}

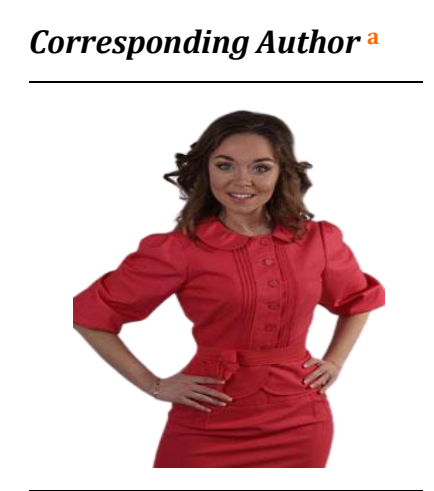

Keywords

choreographic education; COVID-19 pandemic; distance learning; educational process; educational program; higher education; pedagogical education;

\begin{abstract}
The aim of the study in highlight the practical experience of organizing distance learning of choreographers at the Kyiv Municipal Ukrainian Academy of Dance named after Serge Lifar. Practical Significance lies in using the research results in the educational process in teaching disciplines of the choreographic cycle "Theory and methods of working with the choreographic team", "History of choreographic art", "Theory and methods of teaching choreographic disciplines at higher educational institutions" for students of the educational program "Choreography" at the Kyiv Municipal Ukrainian Academy of Dance named after Serge Lifar. The approbation of modern forms of organizing distance learning and its daily analysis in conditions dictated by real events makes it possible to state that it is convenient to work with students-choreographers in practical classes using video communication in the mobile applications Viber, Messenger on Facebook and Instagram, as well as in the mode of video conferences in the Zoom program.
\end{abstract}

International Journal of Health Sciences (C) 2022. This is an open access article under the CC BY-NC-ND license (https://creativecommons.org/licenses/by-nc-nd/4.0/).

\section{Contents}

Abstract

1 Introduction

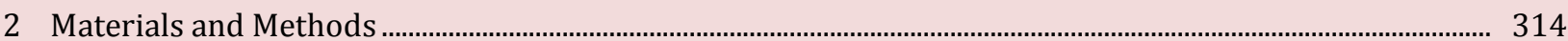

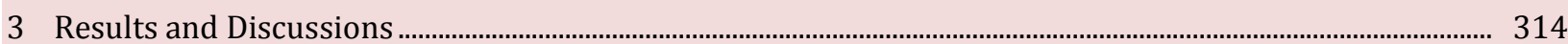

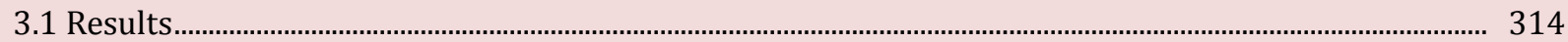

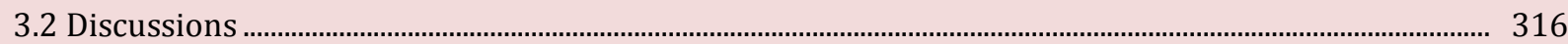

a Kyiv National University of Culture and Arts, Kyiv, Ukraine

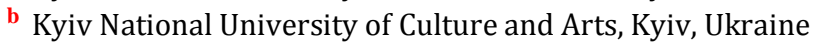

c Kyiv National University of Culture and Arts, Kyiv, Ukraine

d Kyiv National University of Culture and Arts, Kyiv, Ukraine

e Kyiv National University of Culture and Arts, Kyiv, Ukraine

f Kyiv National University of Culture and Arts, Kyiv, Ukraine 


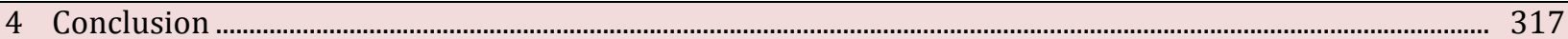

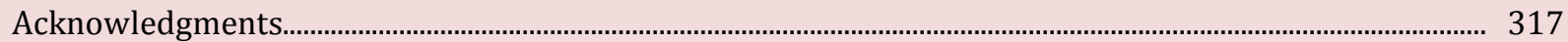

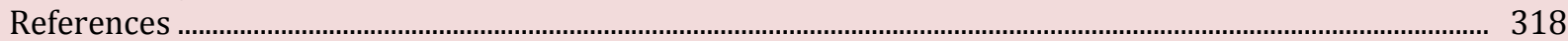

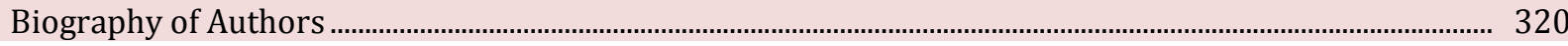

\section{Introduction}

Organization of the educational process for degree-seeking students in the specialty "Choreography", with its practical orientation, has its complications in the distance mode. This, especially, refers to disciplines where the degree-seeking student needs to use special support, receive comments and recommendations from the teacher on the technique of performing movements, complete tasks in tandem with a partner, etc. Distance learning in Ukraine has been implemented for about twenty years, starting with the introduction of the state policy in 2000 in the Concept of Distance Education. At present time distance learning technologies are applied in most institutions of higher education in Ukraine (Zabolotskyi, 2016).

Technological, especially information and communication tools of supporting distance learning, are progressing, which requires their understanding to use for educational purposes, in particular in the sphere of higher education (Van Dinther et al., 2011; Lambrechts et al., 2013). In the light of the introduction of quarantine measures in all educational institutions of Ukraine (regardless of level and subordination), it has become necessary to organize training in distance mode (Aguilera-Hermida, 2020; Bubb \& Jones, 2020).

Unfortunately, most educational institutions were not ready for such a rapid development of events and the necessity for a situational response to changes in the educational process, and the introduction of distance learning practices became a real challenge for the Ukrainian education system at the same time, regional authorities and municipalities in many countries pay considerable attention to education, learning, especially in the context of pandemics and quarantine restrictions (Kliuchnyk et al., 2021; Strikha et al., 2021; Arabadzhyiev et al., 2020). Teachers of higher educational institutions were faced with an urgent problem regarding the constructive organization of a productive educational process in a distance mode.

\section{Literature review}

In the system of modern choreographic pedagogical education, special attention is paid to the graduate's competence model. It is understood as the effective-target basis of the process of professional training of the future choreography teacher, expressed by the systemic quality - competence ensuring his readiness and ability for successful (productive) choreographic activity in professional and social-cultural spheres. Researchers of the issue of professional training of future choreography teachers pay attention to the importance of forming creative competence throughout the training period, which is aimed at developing and disclosing potential opportunities and internal resources of the personality, his full self-fulfillment in educational and further professional activities. For instance, the issues of students' creative development were revealed in the following scientific research: formation of individual style of the future choreography artist (Schupp, 2014; Schupp, 2015); development of the professional creativity's fundamentals of future choreographers in the process of studying (Scheff et al., 2005); formation of professional readiness for the practical activity of future choreographers (Vertinsky, 2010); development of students-choreographers' creative thinking in the process of university training (Triana, 2015); formation of creative activity of students choreographers (Pyzhianova et al., 2020; Vaganova et al., 2019); formation of the creative potential of the future choreography teacher by tools of folk-stage dance (Pyzhianova et al., 2020; Xiang, 2017); professional and creative formation in contemporary dance training (Roche, 2018). Scholars note in their scientific works that it is creativity, which is the basis of choreographic art, should become the core for the training of a qualified competitive specialist who can be creative in the fulfillment of his professional duties, to perceive and create changes, to comprehend and apply innovations in the pedagogical and artistic space.

Despite a large number of studies, distance education in Ukraine has resembled traditional forms of elearning until recent times. It did not provide for the possibility of using innovative forms of organization of the educational process. The rapid development of social events has led to increased attention to the problem of distance learning, namely: the choice of platforms, forms, methods of learning, involvement, and control.

Bigus, O., Bazela, D., Keba, M., Vynokurova, T., Poklad, V., \& Krys, A. (2022). Features of choreography teacher activities in COVID-19 pandemic conditions and distance learning. International Journal of Health Sciences, 6(1), 
The analysis of the source base gives grounds for identifying some contradictions as follows: between the necessity to improve the quality of Ukrainian higher choreographic education and the lack of innovative ways to improve it; between the importance of enhancing the prestige of the arts and the lack of resources and mechanisms to ensure awareness of their importance; between the need to develop the creativity of Ukrainian children and youth by choreography means and the insufficient theoretical and practical study of this topic in comparative pedagogical investigations (Blahova, 2021). The purpose of the academic paper lies in highlighting the practical experience of organizing distance learning of choreographers at the Kyiv Municipal Ukrainian Dance Academy named after Serge Lifar (Ukraine).

\section{Materials and Methods}

To monitor the quality of the educational process during quarantine due to the coronavirus pandemic, an online survey was conducted among students of the Kyiv Municipal Ukrainian Dance Academy named after Serge Lifar (Ukraine). The Kyiv Municipal Ukrainian Dance Academy named after Serge Lifar is an innovative choreographic higher educational institution that has fruitfully combined the methods of classical and folkstage choreography and produced universal performers.

We received 484 answers from students of all courses studying at the Academy, majoring in Choreography. The survey covered the training period from 2000 to 2021 and was conducted using questionnaires, generated in Google form. Respondents responded anonymously and voluntarily. $61 \%$ of respondents - urban population; $20 \%$ live in villages; $19 \%$ - in urban settlements. This survey identified the state and problems of distance learning to find ways to improve it.

\section{Results and Discussions}

\subsection{Results}

Kyiv Municipal Ukrainian Dance Academy named after Serzh Lifar has created a platform for organizing the distance learning process - the Moodle system, which provides the teacher with an e-learning course in a certain discipline and allows working with degree-seeking students online (Moore et al., 2011; Markova et al., 2017). Each teacher of professional disciplines of the specialty "Choreography" has its platform in this system, which contains regulatory documentation, lists of study groups of students, teaching and learning aids. This system and the materials contained in it were used, as a rule, by students who could not attend classes online for a particular reason (Diachenko et al., 2021; Akbarov \& Xabilov, 2021). For instance, the developed educational and methodological complexes for the discipline "Theory and Methods of Contemporary Dance", posted in the Moodle system, contain lecture material according to the plan on topics defined by the curriculum, plans of practical classes, tasks for independent work, assessment system, work program, exam program, additional materials, etc. Each student-choreographer has the opportunity to use the necessary material, to support the answers to questions and complete practical tasks for verification and evaluation by the teacher, and the teacher assesses his efforts in a special journal. In addition, it is very convenient to conduct online chats and forums for discussion in this system (Yeoh, 2012; Alarcón López et al., 2021).

As a result of the survey, when asked how much students like the chosen specialty at the time for the moment, $80 \%$ of respondents have answered that they are satisfied with the specialty they are mastering, however, some find it difficult to answer this question. $2 \%$ of respondents rated their desire to learn at 5 points according to the scale from 0 to 5 points, $46 \%$ - at 4 points, $31 \%$ - at 3 points, and $11 \%$ - from 2 to 0 points. The overwhelming number of students (91\%) is satisfied with the organization of the distance educational process at the Academy; however, there are students, which are mostly dissatisfied (8\%).

When switching to distance learning, $19 \%$ of the surveyed students believe that their knowledge has improved; 35\% said that basically, nothing has changed; 33\% of students believe that knowledge in certain subjects (disciplines) has improved, however, it has deteriorated in a particular number of disciplines; $13 \%$ said that their knowledge had deteriorated. 
The students outlined the most convenient tools and platforms for distance learning, namely: Discord 97\%; Moodle - 50\%; Zoom - 8\%; Google Classroom - 7\%. These results point to the fact that the teaching staff has made the right choice of online learning platform - Discord, which is easy to use for both students and teachers. Teaching and methodological support of disciplines, located in the educational and informational environment Moodle, allows students to work with the relevant courses, processing the lecture material, performing practical tasks, and passing the test control of knowledge in academic disciplines (Martyniv et al., 2021). Along with this, feedback with students is established through Moodle, and communication is supported through the e-course forum. It should be noted that the freedom of teachers on using other online education platforms, services, and Internet resources is not limited by the administration (Daniel, 2020; König et al., 2020; Shomirzayev, 2021).

The most convenient social networks and messengers for distance learning identified by students are as follows: Telegram - 85\%, Viber - 59\%, Instagram - 20\%. The least popular is Facebook Messenger - 1\%. In the course of teaching the theoretical material on the disciplines "Theory and methods of modern dance", "Samples and critique of choreographic art", etc. we have applied such modern forms of organization of the educational process as lecture-webinar, online lecture with errors, lecture-press conference, etc. (Ryan, 2015).

For instance, while studying jazz-modern dance, being online, the teacher has the opportunity to see the whole group of students, identify and analyze errors in the performance of movements and combinations, analyze and learn new material from the discipline. Regarding the remote assessment system, we practice Google forms, Survio, and Kahoot programs for various types of surveys and testing. In addition to the organization of the educational process and the implementation of training tasks within the conditions connected with the manifestation of quarantine, opportunities of students of higher educational institutions for self-improvement have spread in the field of organizing their learning in social networks (Roblyer et al., 2010; Mishra et al., 2020). For instance, students majoring in "Choreography" in parallel with their studies learn online courses in modern choreography from outstanding dancers, take online intensives and marathons on various topics of dance art, watch performances of outstanding choreographers, etc.

About the equipment used by students for learning, then from the indicators, it can be assumed that some of them use several gadgets. The majority - $85 \%$ use smartphones for learning, $50 \%$ also use laptops, $8 \%$ tablets, and another $33 \%$ of students study on desktop computers. $38 \%$ of students believe that distance education will not replace full-time education mode. $34 \%$ indicate a partial replacement. And $27 \%$ of students consider distance education a full-fledged replacement (Table1).

The degree-seeking students were also asked to specify the major benefits of distance learning. $82 \%$ answered that these are home-based, comfortable learning conditions; $34 \%$ - the ability to independently choose sources of information (online platforms, video tutorials, and online textbooks); $22 \%$ - the ability to independently choose the pace of learning; $20 \%$ - the opportunity to choose a convenient time for study, etc.

Table 1

What type of equipment for learning do you use?

\begin{tabular}{lc}
\hline Type of equipment & Answers (\%) \\
\hline Smartphone & 85,1 \\
Laptop & 49,6 \\
Tablet & 37 \\
Desktop computer & 33,3 \\
The latest computer & 0,4 \\
Printer & 0,2 \\
Computer & 0,2 \\
\hline
\end{tabular}

The degree-seeking students have decided on what isn't well suited in distance learning. 55\% believe that the lack of "live" communication with teachers and peers is observed; $38 \%$ note that the level of motivation to study decreased; $34 \%$ pay attention to unsatisfactory technical conditions (poor internet connection, no modern gadgets); $29 \%$ feel the deterioration of their knowledge; $21 \%$ do not have information about the results of an assessment of their academic achievements; $18 \%$ do not understand the criteria for assessing completed tasks, etc.

Bigus, O., Bazela, D., Keba, M., Vynokurova, T., Poklad, V., \& Krys, A. (2022). Features of choreography teacher activities in COVID-19 pandemic conditions and distance learning. International Journal of Health Sciences, 6(1), 
The results make it clear that teachers should strengthen communication with students on the criteria for assessing the tasks performed and remember that the availability of timely assessment motivates students to study, especially within the conditions of the quarantine. Prospective graduates were asked about their life choices after graduation, which would have an advantage for them. Accordingly, $48 \%$ have answered that they dream of having their own business, $39 \%$ will go to work in the chosen specialty, $38 \%$ will look for a job with a good salary, $27 \%$ want to try to go abroad and work there, $19 \%$ will try to get a new specialty, $19 \%$ plan to live as it turns out, as circumstances allow.

The issue of extracurricular work during the period of distance learning remains highly relevant. Students indicate in their answers that they are ready to participate in students' conferences, round tables, training; they want to work in circles, clubs, and studios. $32 \%$ of students have noted that they learn on their own, $29 \%$ sometimes are involved in self-education, $21 \%$ of students have indicated that they do not have enough time for this, $18 \%$ of students indicated that they do not do it (Table 2).

The whole teaching staff tries to diversify the students' life in online mode. The teachers of the cyclic commissions organize and conduct interesting, motivational and useful, and interactive extracurricular online events, namely: round tables, intra-university conferences, meetings with professionals, Olympiads, quizzes, web quests, contests, online communications aimed at the formation of both general and professions competencies of future specialists.

Table 2

Are students involved in additional self-education during quarantine?

\begin{tabular}{lc}
\hline Types of additional self-education & Answers (\%) \\
\hline Independently & 4 \\
Together with classmates & 43,8 \\
I work together with a private tutor & 1,4 \\
I use the Internet & 69,2 \\
With the help of parents & 7,9 \\
I don't do my homework & 6,6 \\
Specialists who have already graduated help me & 0,2 \\
It is my responsibility as a student & 66,1 \\
Strict control over attendance & 58,3 \\
It is difficult to answer & 9.5 \\
Grades & 0,2 \\
Desire to self-develop & 0,2 \\
For no serious reason at all & 0,2 \\
I like everything & 0,2 \\
Are you involved in additional self-education during quarantine? & \\
(additional materials, browsing online resources, webinars, books, etc.) & \\
Yes & 32,4 \\
No & 17,8 \\
I don't have enough time & 21,3 \\
Sometimes & 28,5 \\
\hline
\end{tabular}

Distance learning technologies show their effectiveness, however, at the same time, they cannot completely replace full-time learning, forasmuch as there are many difficulties, namely: lack of live communication, lack of quality Internet connection for students and teachers, technical failures during the fulfillment of tasks by individual students, unequal technical equipment of participants in the educational process, etc.

\subsection{Discussion}

The administration of the Kyiv Municipal Ukrainian Dance Academy named after Serge Lifar (Ukraine) pays great attention to the organization of activities of the educational institution within the conditions of distance learning to ensure fulfillment of educational and professional programs. Distance learning of students in the 
college is systematic and organized according to the schedule of classes (Harper et al., 2004; Tenenbaum et al., 2001).

In contrast, Susilo \& Sofiarini (2021), believe that the WhatsApp Group, which is commonly used in the communication process during a pandemic, may be effective for use as a means of supporting a distance learning system in higher education. In addition to having powerful features, WhatsApp Group is also easily accessible and cheap in terms of data packets used for distance learning (Almarashdeh, 2016). The findings of the study are that in the current era of the pandemic, online distance learning systems should use appropriate and user-friendly online media without compromising their quality. Distance learning at the Kyiv Municipal Ukrainian Dance Academy named after Serge Lifar provides the degree-seeking students (Pratiwi \& Murdiono, 2020; Rahman, 2021).

The Moodle system of distance learning at the Kyiv Municipal Ukrainian Dance Academy named after Serge Lifar provides an opportunity to follow the link to the teacher's YouTube channel, containing video explanations of new training and dance combinations, academic demonstrations of previous courses in modern choreography, experimental findings of degree-seeking students of the second level of higher education, etc. Therefore, the use of a modern educational system Moodle makes it possible for each teacher (including the teacher of the practical course) to form an e-learning course - an environment for productive communication, information exchange, and cooperation of students to increase the efficiency and effectiveness of the educational process (Lotz-Sisitka et al., 2015; Widana et al., 2021).

\section{Conclusion}

The educational process during the period of quarantine continues with the use of distance learning technologies. Organizing quality education using digital technologies, inspiring and motivating students, dealing with technical problems is quite a difficult task. In such conditions, when teachers and students cannot be close and have to work remotely, the interaction between all participants in the educational process, namely: administration, teachers, students, and parents - becomes of particular importance. In addition to the organization of the educational process and the implementation of training tasks within the conditions connected with the manifestation of quarantine, opportunities of students of higher educational institutions for self-improvement have spread in the field of organizing their learning in social networks.

Taking into account a fair number of evident advantages and positive aspects, distance education (like any other form of education) still has certain disadvantages. For ensuring the successful correction of training and adequate assessment, it is important to establish direct contact with the degree-seeking student to be able to check how it works. For this reason, the final quality control of knowledge still needs to be carried out in an intramural session.

In distance learning, direct contact between the teacher and students is lost, as well as between the students, where the latter cease to properly formulate their opinions, state their viewpoints and conduct a discourse. At the same time, this form requires a conscious and motivated approach to a training opportunity. And the most important issue lies in the fact that distance learning cannot be the only form of organization of the educational process, especially in the specialty "Choreography", forasmuch as the lack of practical training, the staging process, collective dance projects, the practice of working in a dance class, the limited study of topics leads to the formation of only fragmentary professional competencies among students and insufficient learning outcomes, which leads to non-compliance with the requirements of the educational and professional program. The promising direction for the development of distance learning in the HEIs of Ukraine is the close cooperation of developers of software products and platforms for distance learning, distance education methodologists, and teachers of the HEIs to develop strategies for using new information technologies in distance learning, as well as for combining the classical education system with distance learning mode.

\section{Acknowledgments}

We are grateful to two anonymous reviewers for their valuable comments on the earlier version of this paper.

Bigus, O., Bazela, D., Keba, M., Vynokurova, T., Poklad, V., \& Krys, A. (2022). Features of choreography teacher activities in COVID-19 pandemic conditions and distance learning. International Journal of Health Sciences, 6(1), 


\section{References}

Aguilera-Hermida, A. P. (2020). College students' use and acceptance of emergency online learning due to COVID-19. International Journal of Educational Research Open, 1, 100011. https://doi.org/10.1016/j.ijedro.2020.100011

Akbarov, A. N., \& Xabilov, D. N. U. (2021). The condition of the oral cavity in patients who have had a viral infection COVID-19. International Journal of Health \& Medical Sciences, 4(4), 381-383. https://doi.org/10.21744/ijhms.v4n4.1796

Alarcón López, C., Decuypere, M., Dey, J., Gorur, R., Hamilton, M., Lundahl, C., \& Sundström Sjödin, E. (2021). Dancing with COVID: Choreographing examinations in pandemic times. European Educational Research Journal, 20(4), 403-422.

Almarashdeh, I. (2016). Sharing instructors experience of learning management system: A technology perspective of user satisfaction in distance learning course. Computers in Human Behavior, 63, 249-255. https://doi.org/10.1016/j.chb.2016.05.013

Arabadzhyiev, D. Y., Buryk, Z., Barshatska, H. Y., Huba, M. I., \& Shashyna, M. V. (2020). Establishing Interterritorial Cooperation of Amalgamated Territorial Communities as a Tool to Increase Their Capacity. International Journal of Management, 11(5).

Blahova, T. (2021). Development Of Choreographic Education In Ukraine In The Structure Of Educational Institutions Of Culture And Art. UNESCO Chair Journal "Lifelong Professional Education in the XXI Century", (3), 58-65.

Bubb, S., \& Jones, M. A. (2020). Learning from the COVID-19 home-schooling experience: Listening to pupils, parents/carers and teachers. Improving schools, 23(3), 209-222.

Daniel, S. J. (2020). Education and the COVID-19 pandemic. Prospects, 49(1), 91-96.

Diachenko, A., Vusyk, H., Bielova, Y., Shurdenko, M., \& Titenko, O. (2021). The educational role in COVID-19 terms of ethnodesign graphic function in higher education practical activities. International Journal of Health Sciences, 5(3), 584-593. https://doi.org/10.53730/ijhs.v5n3.2540

Harper, K. C., Chen, K., \& Yen, D. C. (2004). Distance learning, virtual classrooms, and teaching pedagogy in the $\begin{array}{llll}\text { Internet } & \text { environment. Technology } & \text { 585-598. }\end{array}$ https://doi.org/10.1016/j.techsoc.2004.08.002

Kliuchnyk, A., Shebanin, V., Shebanina, O., Kormyshkin, Y., Rybachuk, V., \& Buryk, Z. (2021). Strategic Factors Quality Of Public Administration In Regional Development: The Experience Of Eu Countries. International Journal for Quality Research, 15(4), 1317.

König, J., Jäger-Biela, D. J., \& Glutsch, N. (2020). Adapting to online teaching during COVID-19 school closure: teacher education and teacher competence effects among early career teachers in Germany. European Journal of Teacher Education, 43(4), 608-622.

Lambrechts, W., Mulà, I., Ceulemans, K., Molderez, I., \& Gaeremynck, V. (2013). The integration of competences for sustainable development in higher education: an analysis of bachelor programs in management. Journal of Cleaner Production, 48, 65-73. https://doi.org/10.1016/j.jclepro.2011.12.034

Lotz-Sisitka, H., Wals, A. E., Kronlid, D., \& McGarry, D. (2015). Transformative, transgressive social learning: Rethinking higher education pedagogy in times of systemic global dysfunction. Current Opinion in Environmental Sustainability, 16, 73-80. https://doi.org/10.1016/j.cosust.2015.07.018

Markova, T., Glazkova, I., \& Zaborova, E. (2017). Quality issues of online distance learning. Procedia-Social and Behavioral Sciences, 237, 685-691. https://doi.org/10.1016/j.sbspro.2017.02.043

Martyniv, L., Sokolova, A., Kurinna, S., Kopeliuk, O., Sediuk, I., \& Khomova, O. (2021). The modern problems and prospects of music formation and art education development during COVID-19. International Journal of Health Sciences, 5(3), 670-680. https://doi.org/10.53730/ijhs.v5n3.2936

Mishra, L., Gupta, T., \& Shree, A. (2020). Online teaching-learning in higher education during lockdown period of COVID-19 pandemic. International Journal of Educational Research Open, 1, 100012. https://doi.org/10.1016/j.ijedro.2020.100012

Moore, J. L., Dickson-Deane, C., \& Galyen, K. (2011). e-Learning, online learning, and distance learning environments: Are they the same?. The Internet and higher education,14(2), 129-135. https://doi.org/10.1016/j.iheduc.2010.10.001 
Pratiwi, P. H., \& Murdiono, M. (2020). The Role of Parents in Strengthening the Character of Honesty When Learning at Home during the COVID-19 Pandemic. In Proceedings of International Conference on Multidiciplinary Research (Vol. 3, No. 2, pp. 25-32).

Pyzhianova, N., Kutsenko, S., \& Voloshyn, P. (2020). The role of folk dance in formation of the choreographer creative potential. Amazonia Investiga, 9(27), 252-259.

Rahman, A. (2021). The Impact of COVID-19 Pandemic on Students' Learning Outcome in Higher Education. AL-ISHLAH: Jurnal Pendidikan, 13(2), 1425-1431.

Roblyer, M. D., McDaniel, M., Webb, M., Herman, J., \& Witty, J. V. (2010). Findings on Facebook in higher education: A comparison of college faculty and student uses and perceptions of social networking sites. The Internet and higher education, 13(3), 134-140. https://doi.org/10.1016/j.iheduc.2010.03.002

Roche, J. (2018). Dancing, identity and place: Balancing subjectivity and technique in contemporary dance training. In Dance Matters in Ireland (pp. 125-143). Palgrave Macmillan, Cham.

Ryan, M. E. (2015). Teaching Reflective Learning in Higher Education-A Systematic Approach Using Pedagogic Patterns.

Scheff, H., Sprague, M., \& McGreevy-Nichols, S. (2005). Experiencing dance: From student to dance artist. Human Kinetics.

Schupp, K. (2014). Igniting Innovation and Shaping the Future: Creative Leadership and Dance Education. Journal of Dance Education, 14(3), 85-86.

Schupp, K. (2015). Teaching collaborative skills through dance: Isolating the parts to strengthen the whole. Journal of Dance Education, 15(4), 152-158.

Shomirzayev, S. (2021). National followers in the students use of educational technologies instruction of interests. International Journal of Linguistics, Literature and Culture, 7(3), 152-157. https://doi.org/10.21744/ijllc.v7n3.1508

Strikha, L., Mamontova, E., Vonsovych, S., Voropayeva, T., Buryk, Z., \& Baranova, O. (2021). The modern experience of lobbying interests in Europe. Estudios de Economia Aplicada.

Susilo, A., \& Sofiarini, A. (2021). Use of WhatsApp Group as Learning Media in Higher Education During the COVID-19 Pandemic. Edunesia: Jurnal Ilmiah Pendidikan, 2(2), 400-410.

Tenenbaum, G., Naidu, S., Jegede, O., \& Austin, J. (2001). Constructivist pedagogy in conventional on-campus and distance learning practice: An exploratory investigation. Learning and instruction, 11(2), 87-111. https://doi.org/10.1016/S0959-4752(00)00017-7

Triana, D. D. (2015). The ability of choreography creative thinking on dance performance. Harmonia: Journal of Arts Research and Education, 15(2).

Vaganova, O. I., Ilyashenko, L. I., Smirnova, Z. V., Bystrova, N. V., \& Kaznacheeva, S. N. (2019). Students' creative abilities development in higher educational institution. Amazonia investiga, 8(22), 701-710.

Van Dinther, M., Dochy, F., \& Segers, M. (2011). Factors affecting students' self-efficacy in higher education. Educational research review, 6(2), 95-108. https://doi.org/10.1016/j.edurev.2010.10.003

Vertinsky, P. (2010). From physical educators to mothers of the dance: Margaret H'Doubler and Martha Hill. The International Journal of the History of Sport, 27(7), 1113-1132.

Widana, I.K., Sumetri, N.W., Sutapa, I.K., Suryasa, W. (2021). Anthropometric measures for better cardiovascular and musculoskeletal health. Computer Applications in Engineering Education, 29(3), 550561. https://doi.org/10.1002/cae.22202

Xiang, Y. H. (2017). Ethnic Folk Dance Class Teaching in the Training of" Non Heritage" Dance Talents in Ethnic Areas. DEStech Transactions on Social Science, Education and Human Science, (ichss).

Yeoh, F. (2012). The choreographic trust: Preserving dance legacies. Dance Chronicle, 35(2), 224-249.

Zabolotskyi, A. (2016). Suchasniy stan distantsiynogo navchannya u VNZ Ukrayini [The current state of distance learning in Ukrainian universities]. Visnyk Dnipropetrovskoho universytetu im. Alfreda Nobelia. Seriia «Pedahohika i psykholohiia. Pedahohichni nauki»[Bulletin of Dnipropetrovsk University. Alfred Nobel. Series «Pedagogy and psychology. Pedagogical sciences»], 2(12), 19-23.

Bigus, O., Bazela, D., Keba, M., Vynokurova, T., Poklad, V., \& Krys, A. (2022). Features of choreography teacher activities in COVID-19 pandemic conditions and distance learning. International Journal of Health Sciences, 6(1), 


\section{Biography of Authors}

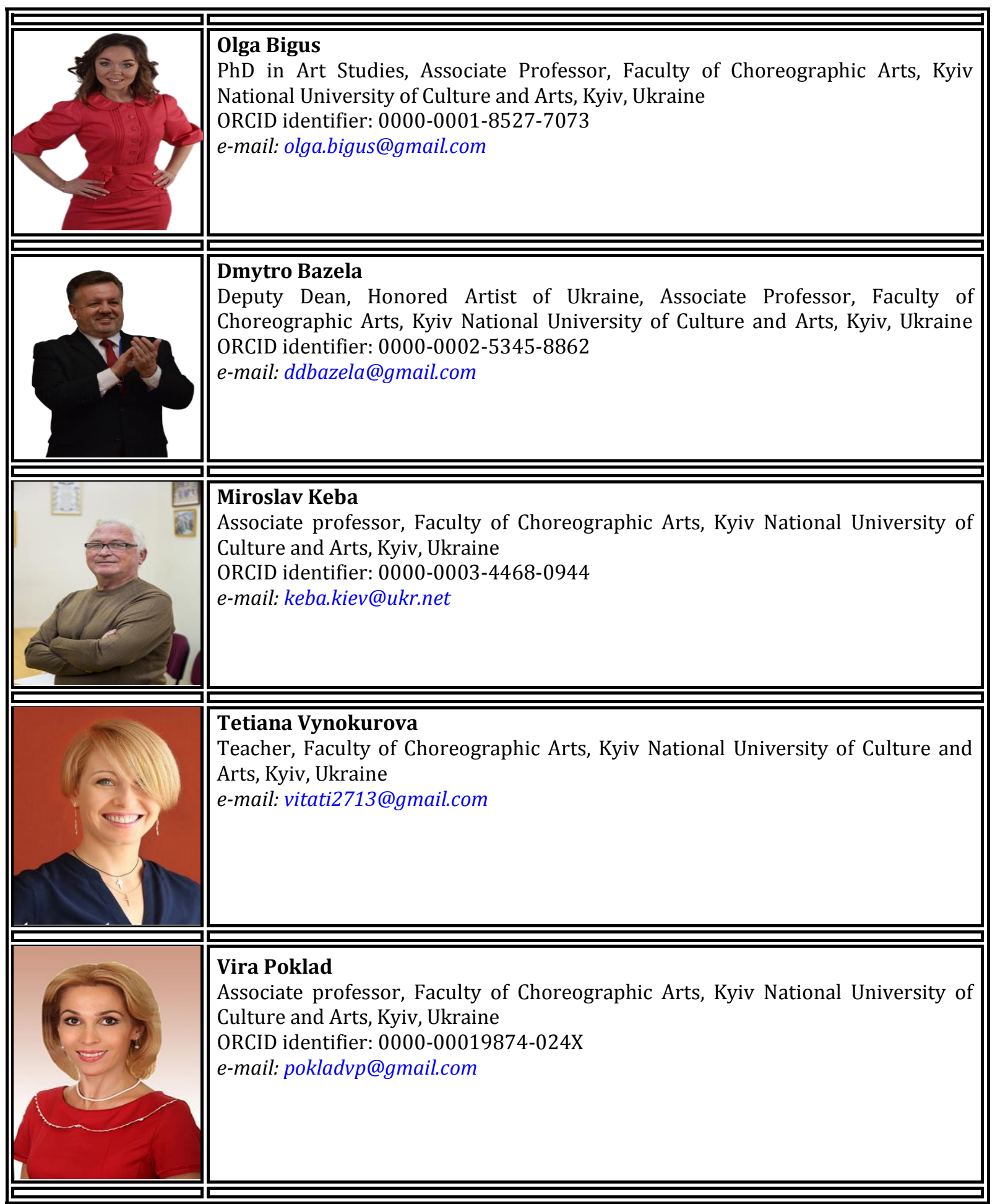




\begin{tabular}{|l|l|}
\hline Andriy Krys \\
Teacher, Faculty of Choreographic Arts, Kyiv National University of Culture and \\
Arts, Kyiv, Ukraine \\
e-mail: krys.rumba@gmail.com
\end{tabular}

Bigus, O., Bazela, D., Keba, M., Vynokurova, T., Poklad, V., \& Krys, A. (2022). Features of choreography teacher activities in COVID-19 pandemic conditions and distance learning. International Journal of Health Sciences, 6(1), 312-321. https://doi.org/10.53730/ijhs.v6n1.4214 